\title{
GOD AND COSMOS AS REALITY: An Inquiry to the Interconnection among Islamic Philosophical Doctrine
}

\author{
Hamid Fahmy Zarkasyi, ${ }^{1}$ Jarman Arroisi, ${ }^{2}$ \\ Mohammad Syam'un Salim, ${ }^{3}$ Muhammad Taqiyuddin ${ }^{4}$ \\ 1,2,3Universitas Darussalam Gontor, Ponorogo - Indonesia \\ e-mail: 1hfzark@unida.gontor.ac.id; 2jarman@unida.gontor.ac.id; \\ 33syamun.salim@unida.gontor.ac.id; 4taqiyuddin@unida.gontor.ac.id
}

\begin{abstract}
In the Islamic intellectual tradition, Being (wujūd) is not limited to physical things. God is also understood as Being; indeed, He is the Absolute Being itself; which of Him, manifests all metaphysical and physical realities. This physical nature is one of the realities caused by God; as well as the metaphysical reality of 'natural law' called 'sunnatullāh' in Islam. It is necessary to know how the power of God can connect to this universe. The question presupposes cosmological research, which needs to involve the study of God and His attributes as well. Methodologically, the verification of Islamic philosophical ideas among Muslim philosophers to Sufis, involves the development of the key concept from tafsir and ta'wil among the Quranic verses (āyat) that discuss God's relationship with Nature itself; from this framework, the relationship between the two can be explained. This article, offers a study of the views of Muslim thinkers: from philosophers to Sufis, about the relationship; which specifically highlights that God and Nature are part of the concept of 'reality' in the Islamic view. The study concludes several important things, especially that God is the Absolute Being; which from Him, another reality as the sign (āyat) of His Existence created. His sunnatullāh again manifests in God's creatures that undergo being devastated and recreated.
\end{abstract}

\begin{abstract}
Abstrak: Dalam tradisi intelektual Islam, realitas (wujūd) tidak terbatas pada halhal yang fisik semata. Tuhan-pun juga termasuk sebagai realitas; bahkan, Ia sebagai Realitas Mutlak itu sendiri; yang mana dari-Nya, terwujudlah segala realitas metafisik maupun fisik. Alam fisik inilah, merupakan salah satu realitas yang disebabkan oleh Tuhan; demikian pula dengan realitas metafisik berupa 'hukum alam' yang disebut 'sunnatulläh' dalam Islam. Yang perlu diketahui, bagaimanakah Kuasa Tuhan 'dapat' terhubung dengan alam? Pertanyaan tersebut mengandaikan kajian kosmologis, yang juga perlu melibatkan kajian atas Tuhan dan Sifat-Nya pula. Secara metodis, pembuktian pemikiran para filsuf muslim hingga para sufi, melibatkan penafsiran dan ta'wïl atas ayat-ayat yang membicarakan relasi Tuhan dengan Alam itu sendiri; yang dari kerangka itulah, hubungan keduanya dapat dijelaskan. Artikel ini, menawarkan kajian tentang pandangan pemikir Muslim, dari filsuf hingga sufi, tentang hubungan tersebut; yang secara khusus menyoroti bahwa Tuhan dan Alam adalah bagian
\end{abstract}


dari konsep 'realitas' dalam pandangan Islam. Kajian tersebut menyimpulkan beberapa hal penting, khususnya bahwa Tuhan, adalah Realitas Mutlak itu sendiri; yang mana dari-Nya, tercipta realitas lain, yakni alam yang mengalami proses hancur (fänn/halak) atau tercipta kembali.

Keywords: al-Ghazālī; God attributes; 'ālam; cosmology; philosopher

\section{A. Introduction}

In Islam, the discourse on reality will at least intersect with various elements, including; The concept of God, which deals with the concept of oneness of God, with its characteristics. Then the discussion regarding cosmology; where the doctrine of creation becomes a serious object of study. Besides, what is not less important is the talk about the reality of things. Several discourses concerning God will be presented. Starting from a discussion of the oneness of God to mentioning the question of His characteristics and the discussion of cosmology. Beginning with the translation of cosmology conceptually, to the discussion related to the cosmic system in the universe. Both the first and the second become an important part of the elements of existence and reality. Apart from these two things, other elements that get a place no less important are those relating to ontology and being. In this section, some important issues will be discussed, namely about the reality of things that are described through the doctrine of atomism, about humans and their relation to Divine reality. ${ }^{1}$

The discussion of God has an essential place in the supersystem. In general, the discourse concerning God in the Islamic intellectual tradition can be categorized into two major groups; philosopher (falāsifah) and theologian (mutakallimūn). Although in fact, theologians have a more varied explanation than the explanation of philosophers, nevertheless both agree that the concept of God is the principle that supports a house in which there are many concepts which are also interconnected; such as the concept of the world, the concept of human being, the concept of Science, and so on. In short, if the explanation of the concept of God has been established, then the other concepts will automatically follow.

${ }^{1}$ Ahmad Rivauzi, "Landasan Filosofis Pemikiran Tasawuf Abdurrauf Singkel tentang Allah, Manusia, dan Alam,” Jurnal Theologia 28, no. 2 (2017): 299-328, https://doi.org/10.21580/ teo.2017.28.2.1451. 


\section{B. The Concept of God}

Concerning the concept of God, al-Ghazāli emphasized that God is transcendent and faithful at the same time. It means that God transcends the boundaries of space and time, he has full will and authority to regulate the whole universe. $^{2}$ For al-Razi; everything depends "contingent being" requires the determinant to realize something. And those who can realize it are only God as a "wajīb al-wujüd ". Besides, God is also close to his servant at the same time. The Qur'an mentions "I (God) am closer to the neck veins." Interestingly, to show the transcendence of God, al-Ghazāil does not refer to God as substance (jawhār), because substance usually refers to worldly objects. ${ }^{3}$ According to him, God is an incorporeal reality outside of space and time. Then the idea of the Qur'an regarding the hands, eyes, the face of God must be interpreted metaphorically (majāz). ${ }^{4} \mathrm{Al}$-Ghazālī also mentions that God's essence is unique, individual; for it does not require a companion, and nothing resembles Him, He is eternal. ${ }^{5}$ According to al-Farabi, the oneness of God means that God is perfect, has no shortcomings, and stands independently because He does not depend on other entities. ${ }^{6}$ Similar to this, al-Ghazāli mentions that the oneness of God has the meaning of the negation of anything that matches Him and affirms its essence. Besides, the term "one" means denial of plurality; that He does not accept division, then does not amount, and does not have the quantity of both small and large parts (lā kammiyah wa lā juz' wa lā miqdār). God cannot be equated in any way and does not have a partner. God is perfect and nothing equals both essence and nature.7 Furthermore, al-Ghazālī identified this oneness of God into three

2Yasin Ceylan, Theology and Tafsir in the Major Works of Fakhr al-Din al-Razi (Kuala Lumpur: ISTAC, 1996), 85; Abū Hamīd Muhammad ibn Muḥammad al-Ghazālī, "al-Hikmah fi Makhlūqātillāh," in al-Qusūr Awāli min Rasā'il al-Ghazālī, ed. Mușțafā Abū al-'Alā, 3rd ed. (Cairo: Maktabah al-Jundi, 1972), 11-15, QS. Āli Imrān [3]: 190.

${ }^{3}$ Abū Hamīd Muhammad ibn Muhammad al-Ghazālī, Tahāfut al-Falāsifah, ed. Michael E. Marmura (Utah: Brigham Young University Press, 2000), 41; Abū Hamīd Muhammad ibn Muhammad al-Ghazālī, al-Iqtiṣād fi al-I'tiqād, ed. Insaf Ramaḍān (Beirut: Maktabah Kutaibah, 2003), 69-70.

${ }^{4}$ al-Ghazālī, Tahāfut al-Falāsifah, 56-58.

${ }^{5}$ Abū Hamīd Muhammad ibn Muhammad al-Ghazālī, al-Arba'în fi Ușūl al-Dīn, ed. Mușțafā Abū al-'Alā (Cairo: Maktabah al-Jundi, n.d.), 13.

${ }^{6}$ Abū Nașir Muhammad al-Farabi, Kitāb al-Sìyāsah al-Madaniyyah, ed. F. M. Najjar (Beirut: Dar El-Mashreq Publisher, 1964), 42.

${ }^{7}$ al-Ghazālī, al-Iqtiṣād fi al-I'tiqād, 69. 
theories. First, the theory of "divine uniqueness" that God-as mentioned earlier-is an entity that is different from anything and anyone. ${ }^{8}$ So, the characteristics of God cannot be imagined by anything; like anything, humans know. This means that the knowledge of God has a far divergence from the knowledge of His creatures. ${ }^{9}$

Furthermore, the indifferent explanation was also explained by alThahanawi. In 'aqĩdah al-Tahōwiyah, he explained that the purpose of a verse of the Qur'an "laisa kamithlihi shai'un" is that God has the will for all things; everything other than Himself is called faqiir, all matters become easy at His will, and He does not need anything but Himself. ${ }^{10}$ According to al-Faruqi's tawhïd as a worldview, the principle of duality means dividing reality into two types; khāliq and makhlüq. The first type has only one entity, the transcendent creator Allah. While the second type, is the order of space and time, experience, and so on which includes all beings, the world of objects, plants, animals, humans, jinn, angels, heaven and earth, to heaven and hell. These two types of reality-namely khāliq and makhlūq —are completely different in their existence, anthology and existence. In short, it is forever impossible to happen that one is entered into another; the Creator can't be ontologically transformed and changed to become a creation, and vice versa. ${ }^{11}$

The second theory states that the oneness of God comes from the human experience of recognition "there is no God but Allah [lā ilāha illā Allāh]". Al-Ghazālī clarified this experience into four forms of expression: (a) the level of the statement in the form of speech, but at the same time accompanied by denial of the truth in his heart. This expression occurs at the level of the hypocrites. (b) Expressions accept the truth from the statement of the oneness of God both in the heart and in speech. This is the tawhìd of ordinary people, which is practiced by ordinary people and applies in general. (c) The degree to which humans-as seekers-feel that the diversity of things is produced by the One and the

${ }^{8}$ Abū Hamīd Muhạmmad ibn Muhammad al-Ghazālī, al-Maqșād al-Asnā' min Asmā' Allāh alHusnā, ed. Mạ̣mūd al-Nawāwi (Cairo: Maktabah al-Kulliyat al-Azhariyyah, n.d.), 34.

${ }^{9}$ al-Ghazālī, al-Arbaî̀n fi Ușūl al-Dīn, 18, 23. 2001), 14.

${ }^{10} \mathrm{Abū}$ Ja’far al-Ṭahāwi, al-Aqīdah al-Ṭahāwiyyah, ed. Majdi Abū 'Arisy (Beirut: Dār al-Bayariq,

${ }^{11}$ Ismāīil Rājī al Fārūqū, al-Tawhid: Its Implications for Thought and Life (Virginia: International Institute of Islamic Thought, 2000), 10-11, https://doi.org/10.2307/j.ctvk8w28n. 
Almighty, God. This expression is a feature of tawhid fi'li (trust in an Actor) which can only be achieved by humans who approach the God "al-muqarrabūn". (d) The level at which humans do not see any existence except the existence of God. This level is filled by the siddiqūn.12

Furthermore, at this last level, Sufis call it the term "al-fanä' fi al-tawhid". This means that the situation is unconscious of anything in seeing oneself and whatever is created even outside of it all. This happens with the full awareness that God's ownership as the Absolute Reality is too great. ${ }^{13}$ So if we pay close attention, the argument of the oneness of God mentioned earlier is following the concepts of al-haq and al-haqiqah and the reality of existence. The first two levels are descriptions of the meaning of truth, while the last two are under the meaning of reality.

The third theory refers to God-world relations in two different phrases; action phrases and expressions phrases. ${ }^{14}$ God is the only entity capable of wanting and acting. In other words, God is the real Agent ( $f i$ 'it), the true actor in all existence. This is the stage where humans feel nothing but "al-Wahid alHaqq". Then because God is called the only real reality, the result is that everything other than himself will be destroyed, the Qur'an mentions "kullu shai in hālikun illā wajhah".15 It means that outside of God's reality cannot be called "al-Mawjūd al-Haqq".16

\section{The Attributes of God}

In addition to the oneness of God discussed earlier, in the concept of God there is also an argument concerning the attributes of God. This argument inspires an interesting view of the "tashbinh" which says that between God and his creatures, especially humans, it is possible for similarity in positive knowledge about God. This interesting statement starts from a hadìth qudsī that reads

\footnotetext{
${ }^{12}$ Harun Nasution, Falsafat dan Mistisisme dalam Islam (Jakarta: Bulan Bintang, 1978), 76.

${ }^{13}$ Abū Ḥamīd Muhammad ibn Muhammad al-Ghazālī, Ihyyā' Ulūm al-Dīn, ed. 'Abd al-'Azīz Sirwān (Beirut: Dār al-Qalam, n.d.), 230-32.

${ }^{14}$ Abdul Haq Ansari, "The Doctrine of Divine Command: A Study in the Development of Ghazāli's View of Reality," Islamic Studies 21, no. 3 (1982): 1-47, https://doi.org/10.2307/ 20847207.

${ }^{15}$ QS. al-Qașaș [28]: 88

16al-Ghazāli, Ihyā' 'Ulūm al-Dīn, 83-84.
}

JURNAL THEOLOGIA — Volume 30, No. 2, December 2019 
"kuntu kanzan makhfiyyan"; I was a Hidden Treasure (and) I wanted to be known, so I created Creation". Here, God expressed his desire to be known by His creatures-especially humans-so He created the universe as a medium, through which the human being can ultimately recognize its properties glorious; sifāh as His attributes. ${ }^{17}$

Those are reasonable because something can be known well when between subjects (who know) with objects (known) found in common. ${ }^{18}$ This means that when speaking of the nature of God, humans can find some similarities, which lead to allowing people to know God positively. As an example; humans can - to some extent-know the nature of "knowing" God because even humans have the nature of knowing. ${ }^{19}$ The same thing is also believed by al-Ghazālī. He divided the nature of God into seven characteristics; Alive, All-Knowing, All Willing, All-Powerful, All-Seeing, All-Hearing, Most Speaking, all are called the nature of sifät al-ma'nā. ${ }^{20}$ For al-Ghazālī sifät cannot be separated from the Divine dimension, because for him God cannot be understood without it. Apart from that, the attachment of character to God has a logical consequence that God is a living entity and describes Him as having the ultimate will which is the cause of creation. God is an agent who is omniscient, most powerful, he does what he wants, and likes.

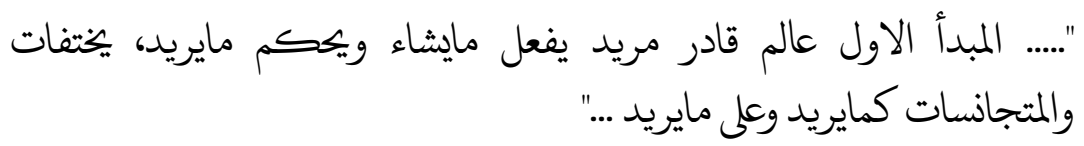

"..... the First Principle is knowing, powerful, willing; that He enacts as He wishes, governs what He wills, creates things that are varied and things that are homogeneous as He wills and in the way He wills"21

17William C. Chittick, The Self-Disclosure of God: Principles of Ibn al-Arabi's Cosmology, ed. Seyyed Hossein Nasr (New York: State University of New York, 1998), 44-48.

${ }^{18}$ Everett K. Rowson, A Muslim Philosopher on the Soul and Its Fate (New Haven: American Oriental Society, 1998), 264-65.

${ }^{19}$ Abdul Hye, "Aliran Asy'ariyah," in Aliran-Aliran Filsafat Islam: Mu'tazilah, Asy'ariyyah, Maturidiyyah, Thahawiyah, Zhahiriyah, Ikhwan al-Safa, ed. M. M. Sharif (Bandung: Nuansa Cendekia, 2006), 63.

${ }^{20}$ Abū Hamīd Muhammad ibn Muhammad al-Ghazālī, Tahāafut al-Falāsifah, ed. Sulaymān Dunyā (Cairo: Dār al-Ma'āirif, 1966), 29.

21al-Ghazālī, 76. 
It should be noted, as previously reviewed that God does have traits, but in truth, these traits are different from the essence of God itself; both have differences. In this regard, al-Ghazāli introduced four principles; first, that nature is recognized not by His essence. Because to mention God, it does not mean knowing God is powerful, and so on. Second, all of God's attributes live according to His essence. Third, all the attributes of God are eternal. Fourth, that all "sifät al$m a^{\prime} n \bar{a} "$ the nature of God-such as the Supreme willing-is eternally continuously based on him. ${ }^{22} \mathrm{Al}$-Ghazālì's argument about this trait was criticized by the Mu'tazilites. Because for them, if God has character, that character is eternal as God. This has an impact on the existence of dual immortality "ta'addud alqudam $\bar{a}$ ". Al-Ghazāli himself dismissed the accusation by stating that the nature of God is not the same as God, even different from the essence of God itself. This defense of al-Ghazālī is known as "lā hiya Huwa wa lā hiya ghayruhu".23

On another occasion, Ibn Arabi described God's character with the cosmos. As Chittick explains, for Ibn Arabi the nature of 'Most knowing' for example, indicates God's knowledge of the entire reality of the universe. In other words, the relationship of knowledge is formed between God and what God knows. Because God is a creator, so the nature of the relationship of creativity is formed between God and His creation. ${ }^{24}$

From the explanation above, it can be concluded that the discourse relating to God; both His oneness and His attributes have a profound influence on the concepts of reality and existence. The concept of God is closely related to the concept of God as "al-Mawjüd al-Haqq" or "The Real Existence". God is the only source of existence, the only entity that creates the universe. So, it is commonly understood that the concept of God and His attributes are the foundation of the concept that plays an important role in providing more detailed explanations regarding the Absolute Reality, as well as other realities or creations.

\section{The Concept of Cosmology}

In simple terms, cosmology is a science that discusses and learns about all things related to nature. ${ }^{25}$ According to Raghib al-Isfahani, the word 'âlam which

${ }^{22}$ al-Ghazālī, al-Iqtișād fi al-I'tiqād, 114,121,123.

${ }^{23}$ al-Ghazālī, 138-39.

${ }^{24}$ Chittick, The Self-Disclosure of God: Principles of Ibn al-Arabi's Cosmology, xvii.

${ }^{25}$ Ahmad Fuad al-Ahwani, al-Falsafah al-Islāmiyyah (Cairo: al-Maktabah al-Thaqafiyyah, 1962), 132; Donald Smith, The Cosmos (Canada: Benyamin WA, 1976), 403; Poejawijatna, Manusia dan 
connotes the cosmos, comes from the word 'ilm, a terminology commonly used in Arabic to indicate "knowledge". This terminology itself comes from the root word 'ain-lam-mim or 'ālam. The basic meaning contained in the root of this word is 'âlamah which means direction. Still, according to al-Isfahani, al-âlam is a trace or sign that makes something known "al-athär alladhì yu'lam bihi shāy". So in general, 'âlam means the universe, semantic nature or cosmos. Cosmos itself covers not only what is around humans, but also what is in humans themselves. This is known as the macrocosm "al-ālam al-kabïr" and the microcosm "al-älam saghïr". The first shows nature in the sense of the universe, while the second means specific to the human being created according to the first natural reference. ${ }^{26}$

Imām al-Ḥarāmayn al-Juwayni explained that nature can be called 'âlamah because it is a clue built to show the existence of the owner of nature. All the events in the world, their parts and particles are clues that show the existence of God. ${ }^{27}$ If observed, all the terminology mentioned earlier relates logically to the other keywords like "khalq" (creation), the terms also equivalent with "khāliq" (creator) and "makhlūq" also "khuluq" plural "akhlāq" (character of the internal dimension of a person/'makhlüq' ${ }^{28}{ }^{28}$ Khalq according to Ibn Manzur explains the creation of something in a completely new form "ibtidā' al-shay' 'alā mithāl lam yusbaq ilayh" and also "al-taqdī" gives a clear measure of [something]. The same thing was expressed by al-Rāzi, that basically 'nature means the same as 'âlamah, while al-älam means "al-khalq" (creation). ${ }^{29}$

The same thing was explained by Ibn Rushd. He put forward two wellknown arguments "dalīl al-ināyah" proof of help and "dalīl al-ikhtirä" proof of

Alamnya (Jakarta: Bina Aksara, 1983), 13-5; Jamīl Salīb, Tarīkh al-Falsafah al-'Arābiyyah (Beirut: Dār al-Kitāb al-Ranani, 1970), 229; Ibrāhīm Anīs, al-Mu'jam al-Wāsiṭ (Cairo: Dār al-Ma'ārif, 1972), 624; Abū Hamīd Muhammad ibn Muhammad al-Ghazālī, Mi'yār al-'Ilm (Cairo: Dār al-Ma'ārif, 1960), 366; Simon Blackburn, Oxford Dictionary of Philosophy (Oxford: Oxford University Press, 1996), 85.

${ }^{26}$ al-Raghib al-Asfahani, Mufradāt Alfāz al-Qur'ān, ed. Sufyan 'Idnan Dawari (Beirut: al-Dar alShamiyah, 2009), 581; Su'ad al-Hakīm, al-Mu'jam al-Ṣūfi: al-Hikmah fi Hudūd al-Kalīmah (Beirut: Dandarah lil Ṭibā'ah wa al-Naṣr, 1981).

27Imām al-Juwaini, Luma' al-'Adillah, ed. Fawqiyah Ḥusayn Mạ̣mūd (Cairo, 1965), 76.

${ }^{28}$ Mohd Zaidi Ismail, "The Cosmos as the Created Book and Its Implications for the Orientation of Science," in A Companion Worldview of Islam: Course Materials for Wise Summer School (Kuala Lumpur: CASIS-UTM, 2015), 69.

${ }^{29}$ Muhammad bin Mukrim bin 'Ali Abū al-Faḍl Jamāl al-Dīn Ibn Mandhūr, Lisān al-Arab (Beirut: Dār al-Shadir, n.d.). 
creation. ${ }^{30}$ It is interesting to examine, in the submission of the second argument Ibn Rushd put forward evidence of the creation of nature that such an ordered nature is planned and controlled, and that is clear evidence of creation. Because an ordered nature can't occur by itself without a creator. So, God became the cause of existence from the existence of the universe. The argument mentioned by Ibn Rushd is not only related to the theory of causality but also interspersed with the motion theory which points out that this nature is always in motion and that motion is caused by the existence of a driver. And what drives is God Himself.

However, the argument put forward by Ibn Rushd is also built on two important things: first, everything that exists in this world, exists because it was created and preserved; such as the willingness of food needs and so on. While the second, states that every creation must have its creator. Therefore, people who want to know the form of God must know the nature of things, otherwise, they will not be able to know the nature of creation. Furthermore, according to Ibn Rushd-the verses of kawniyah which describe the existence of God-if carefully considered there will be three fragments; verses that contain explanations with the model of proof of al-ināyah, verses which explain through the fragments of the al-ikhtirä' and finally, verses that combine the two. ${ }^{31}$ Here, cosmology in a certain understanding gives proof of the relationship between God as Absolute Reality, and the universe which is also called reality despite its relativities.

The argument concerning creation which was discussed earlier is the application of the principle of 'causality' or the causation of the existence of creation. Everything that is not temporal is created because of God's will. In the same way, al-Ghazāli positioned God as an agent for the existence of everything. Therefore al-Ghazāli chose to use the term 'actor' rather than the term 'cause' used by philosophers. ${ }^{32}$ According to al-Ghazālī, if the term used; God is the

\footnotetext{
${ }^{30} \mathrm{Abū}$ al-Walid Muhammad ibn Ahmad ibn Rushd, al-Kashf 'an Manāhij al-'Abdillāh fi 'Aqā'id Ahl al-Millah (Beirut: Markaz Dirasat al-Wạhdah al-'Arabiyyah, 1997), 24-28.

31Ibn Rushd, 152; Sujiat Zubaidi Saleh, "Kritik Ibn Rusyd terhadap Pandangan Para Filsuf tentang Ketuhanan," Tsaqafah 5, no. 1 (2009): 97, https://doi.org/10.21111/tsaqafah.v5i1.149.

${ }^{32}$ Hamid Fahmy Zarkasyi, Al-Ghazali's Concept of Causality: With Reference to His Interpretations of Reality and Knowledge (Kuala Lumpur: IIUM Press, 2010), 103; Hamid Fahmy Zarkasyi, "Epistemological Implication of Al-Ghazzālīs Account of Causality," Intellectual Discourse 26, no. 1 (2018): 51-73, https://journals.ium.edu.my/intdiscourse/index.php/islam/article/ view/1131.
} 
cause. That means His action goes with His essence. As a result, the act will be eternal as His essence. And if God acts through His essence, His essence demands His impossible actions. In other words, God is forced to act; God is indirectly considered to have no choice and power to reject something. So, what is right is that action comes from a meaning added to the essence called "sifäh," so God is more accurately called "fäill" or actor.

Furthermore, the term 'actor' is considered more appropriate because 'actors' do not act or create because of a need. He creates naturally (bi al-țabí). Agreeing to this opinion, Ash'arite calls God as an actor, not a cause. ${ }^{33}$ Even so alBaqilani in his book Tamhìd mentions; this world is impermanent; therefore, he must have a creator, and this creator must be a living agent, who knows and wants. In short, God does not act through any need for His nature. ${ }^{34}$ In another explanation, al-Ghazāli argues that the term agent or actor contains the idea of will and knowledge of what he wants. Al-Ghazāli gave a simple description; if someone throws someone else into the fire and ends up dead, then the real person who throws is the perpetrator of the murder, and not fire, because the person who throws- the first-has the will and knowledge. Thus, God is an entity that creates, regulates, and knows everything. Everything is created carefully and measurably. The universe is made with His schema of wisdom and knowledge.

\section{E. The Cosmic System}

In Mishkāt Anwār, al-Ghazāli described the cosmos as an entity formed by three worlds; real-world or physical realm ('âlam al-mulk), the world is invisible; imaginal realms ('âlam malakūt) and the divine world ('ālam jabarūt). The first world, (al-mulk) called the world of creation ('älam al-khalq) can also be called the world of the reason ('ālam al-his). Here it can be seen that this first world is a material world that can be seen by the naked eye (bașār) 'tangible', so often referred to as 'âlam al-mulk wa al-shahādah, indicating the world of sensible phenomena; this world has no real existence. Because it can only be sensed, the world has the lowest position in the world.

\footnotetext{
${ }^{33} \mathrm{Abu}$ al-Hasan al-Ash'arī, Kitāb al-Luma', ed. Richard McCarty (Beirut: Imprimerie Catholique, 1953), 6-8.

${ }^{34}$ al-Baqillani, Kitāb Tamhīd al-Awāỉl wa Tadkhīl al-Daläil, ed. 'Imād al-Din Aḥmad Haydar (Beirut: Mu'assasatal-Kutub al-Thaqāfiyyah, 1987), 44,47-48, 52-56.
} 
While the second world ('ālam al-malakūt), is a non-sensory world; world of spirits, angels, divine. Malakūt world can only be known by the inner and spiritual eyes (bașirah), therefore this type of world is also often referred to as "ālam al-ghaib wa al-malakūt" an invisible world. It has forms that are similar to physical forms, but actually, they do not have physicality, like those of the physical world. This human nature often encounters in dreams where zahir is seen and looks so clear in its forms, but has no physical form. Another example can be found in the shadow of a mirror. The shape looks so obvious to the eye, because it has an identical physical form, but does not have physicality. But there are also other titles between them; 'âlam al-amr, ${ }^{35}$ a great, eternal spiritual world because it never changes and has a real existence. ${ }^{36}$

However, even though both have different intentions, the truth is that both are a pair of inseparable understandings. Like the body with spirit or ratio with feeling. This means that the difference between mulk and malakūt is like a comparison between hands and faces. Al-Ghazāli called mulk representing the world while malakūt represented the hereafter. So, there is a third type of world; 'ālam al-jabarūt. In simple terms, the world of al-jabarūt is a world between mulk and malakūt. ${ }^{37}$ In Sufi discourse, the world of al-jabarūt is understood with various meanings. Al-Nasafi, for example, placed jabarūt as an unreachable region in the potential world, its position was above the world of mulk and malakūt. Ibn Arabi called it "a'yān tsābitah" archetype permanent. ${ }^{38}$ Unlike Ibn Arabi, Sa'duddin Hamuyya calls it something that cannot be changed "mahiyyah" or essence, "mumkināt" things that are possible and have universal values "kulliyāt".39 Unlike the previous one, al-Hallaj called the world jabarūt as "Hāqq" Truth, while the malakūt world he called the Reality "haqiqqah".40

\footnotetext{
${ }^{35}$ Seyyed Hossein Nasr, An Introduction to Islamic Cosmological Doctrines: Conceptions of Nature and Methods Used for Its Study by the Ikhwān Al-Safä, Al-Bīrūnī, and Ibn Sinā (London: Thames and Hudson, 1978), 44-74; Annemarie Schimmel, Mystical Dimensions of Islam (Carolina: The University of North Carolina Press, 1975), 270.

36al-Ghazālī, Iḥyā' 'Ulüm al-Dīn, 234.

${ }^{37}$ al-Ghazālī, 234.

38'Abdullāh al-Anșāri, Manāzil al-Sāîiñn, ed. A. Shirvani (Iran: Intisyarāt-i Furughi, 1380), 32; Samer Akkach, Cosmology and Architecture in Premodern Islam: An Architectural Reading of Mystical Ideas, ed. Seyyed Hossein Nasr (New York: State University of New York Press, 2005), 114.

${ }^{39}$ al-Anșāri, Manāzil al-Sāirīin, 32.

${ }^{40}$ L. Massignon, Halläj: Mystic and Martyr, trans. H. Mason (Princetown: Princeton University Press, 1994), 113.
}

JURNAL THEOLOGIA — Volume 30, No. 2, December 2019 
On the other hand, Mahmud al-Qaysari called the world jabarūt with the first world; external existence, the world of intellect and soul that is nonmaterial. Also called the world of spiritual reality. According to him, this world existed before the world of mulk and malakūt began and existed first. He added that this third world included permanent archetype "a'yān tsābitah" from divine knowledge. ${ }^{41}$ In another explanation, the world of jabarüt is also interpreted with the world of the name and nature of "asmā ' wa sifät", besides that it can also be called the world of "barzakh".42 It means that this world and the creatures in it are called abstract substances "al-jawāhir al-mujarradah." The Division of nature into Malakūt; al-Mulk; Jabarūt which was mentioned earlier can be illustrated as Figure 1.

In short, from the explanation above, it can be concluded that cosmology in the Islamic tradition does not only lead to physical sensory things; even though the object of study covers the cosmos, but it also covers everything to the spiritual aspect. This means that reality is seen not only in objects that can be seen, but also for non-visible ones at once, and both lead to the same point and are interconnected with one another. ${ }^{43}$

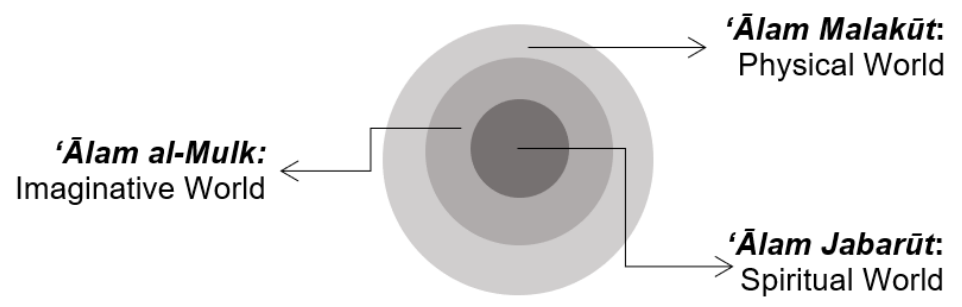

Figure 1.

The Division of Nature into Malakūt; al-Mulk; Jabarūt

\footnotetext{
${ }^{41}$ Akiro Matsumoto, "Unity of Ontology and Epistemology in Qaișari's Philosophy," in Consciousness and Reality, Studies in Memory of Toshihiko Izutsu, ed. Sayyid Jalāl al-Dīn Āshtiyānī et al. (Tokyo: Iwanami Shoten Publisher, 1998), 377.

42'Ali bin Muhammad bin 'Ali al-Zayn al-Sharīf al-Jurjani, Kitāb al-Ta'rīfāt (Beirut: Dār al-Kutub al-'Ilmiyyah, 1983), 88; Kamāl al-Dīn 'Abd al-Razāq al-Qashani, Iștilāhạat al-Ṣūfiyyah, ed. Kamāl Ibrāhīm Ja'far (Cairo: al-Hay'ah al-Mișriyyah al-'Ammah li al-Kitāb, 1981), 1, 106.

${ }^{43}$ Mohd Zaidi Ismail, "Kosmos dalam Pandangan Hidup Islam dan Orientasi Sains Masyarakat Muslim," Islamia: Jurnal Pemikiran dan Peradaban Islam 3, no. 4 (2008): 5-25.
} 
The existence of the cosmos also leads to Ash'arite atomic theory. Ash'arite believed that substance and accidents are very closely related to the universe; an entity that manifests because of God's creation. It means the world itself consists of two different elements, namely substance, and accident (jawhär wa al-'arḍh). That substance or atom is a locus that gives substance to the accident. This means that an accident cannot exist in other accidents, but it exists only in atoms or objects composed of these atoms. So, on the contrary, an object cannot be separated from accidents, both positive and negative; like the smell, color, ${ }^{44}$ knowledge and so on. ${ }^{45}$

The existence of the cosmos also leads to Ash'arite atomic theory. Ash'arite believed that substance and accidents are very closely related to the universe; an entity that manifests because of God's creation. It means the world itself consists of two different elements, namely substance, and accident (jawhär wa al-'arḍh). That substance or atom is a locus that gives substance to the accident. This means that an accident cannot exist in other accidents, but it exists only in atoms or objects composed of these atoms. So, on the contrary, an object cannot be separated from accidents, both positive and negative; like the smell, color, ${ }^{46}$ knowledge and so on. ${ }^{47}$

Furthermore, the main characteristics of the atomic theory of Ash'arite can at least be divided into three distinctive characters. First, atoms do not have a quantity. It does not have a definite size (kām) and is homogeneous. In other words, atoms are entities that do not have length or width but are integrated to form objects that have dimensions. Second, atoms have a finite or certain

${ }^{44}$ Fakhr al-Dīn al-Rāzi, Mafātīh Al-Ghayb (Beirut: Dār 'Ihya' al-Turath al-A'rab, 1420), 347; Tariq Jaffer, "Fakhr al-Dīn al-Rāzī on the Soul (al-Nafs) and Spirit (al-Rūh ): An Investigation into the Eclectic Ideas of Mafātīh al-Ghayb," Journal of Qur'anic Studies 16, no. 1 (2014): 93-119, https://doi.org/10.3366/jqs.2014.0133.

${ }^{45}$ Osman Bakar, Tauhid dan Sains: Esai-Esai tentang Sejarah dan Filsafat Sains Islam, ed. Yuliam Liputo (Bandung: Pustaka Hidayah, 1994), 101; al-Baghdadi, Kitāb Ușūl Al-Dīn (Istanbul: Matba'ah alDawlah, 1928), 33.

46Fakhr al-Dīn al-Rāzi, Mafātīh Al-Ghayb (Beirut: Dār 'Ihya' al-Turath al-A'rab, 1420), 347; Tariq Jaffer, "Fakhr al-Dīn al-Rāzī on the Soul (al-Nafs) and Spirit (al-Rūh ): An Investigation into the Eclectic Ideas of Mafātīh al-Ghayb," Journal of Qur'anic Studies 16, no. 1 (2014): 93-119, https://doi.org/10.3366/jqs.2014.0133.

${ }^{47}$ Osman Bakar, Tauhid dan Sains: Esai-Esai tentang Sejarah dan Filsafat Sains Islam, ed. Yuliam Liputo (Bandung: Pustaka Hidayah, 1994), 101; al-Baghdadi, Kitāb Ușūl Al-Dīn (Istanbul: Matba'ah alDawlah, 1928), 33. 
number. This opinion is based on verse 28 of the Qur'an, Surah al-Jin "and He calculates all things with numbers". 48 Here it is clear that the atomic theory of the Ash'arite was in opposition to the Greek atomic school which saw the atom as an infinite number of things. While the third character, the nature of the atom can disappear. Atoms in their view cannot survive temporarily. At certain moments atoms can manifest through existence, in other moments the atoms can disappear and disappear without a trace. According to them-because of their temporary existence-then God was involved in presenting accidents. Because as al-Ghazālī stated that the incident "lā yatașawwaru al-baqā"' does not have endurance. ${ }^{49} \mathrm{Al}$-Baqillani in Tamhì $d$ also mentions accidents as something that is not eternal, it rests on the body and atoms and will disappear after the process of its realization. The inability of substance and accidents is a logical consequence of the theological belief that God is directly involved not only in manifesting things but also in presenting forms of existence. 50

From the accumulated exposure above, there are at least two important points that need to be observed. First, that God as absolute reality is the creator of the universe. God also acts as a constant foundation for beings. Therefore, atomic changes can occur only when God recreates an atom in a new state, and occurs in seconds and take place in succession. Secondly, to achieve existence such as motion, silence, aggregation, and separation, God created atoms together with accidents. Then in each atom has a large number of accidents. And the accident is not able to survive in the sense of not accepting eternity, because it shrinks continuously. Therefore, the doctrine of jawhār wa al-'ardh in the ontology of creation leads to the rejection of the existence of secondary causality in the universe. That the law of nature will not occur except with the will of the creator as the Absolute Reality of God.

${ }^{48}$ QS. al-Jīn [72]: 28.

${ }^{49}$ al-Ghazālī, al-Iqtișād fi al-I'tiqād, 42; Imron Mustofa, "Fisika Atom sebagai Basis Filosofis Ilmu dalam Perspektif al-Ghazali," Epistemé: Jurnal Pengembangan Ilmu Keislaman 12, no. 1 (2017): 5375, https://doi.org/10.21274/epis.2017.12.1.53-75; Binyamin Abrahamov, Ilmu Kalam: Tradisionalisme dan Rasionalisme dalam Teologi Islam, ed. Nuruddin Hidayat (Jakarta: Serambi Ilmu Sementara, 2002), 75-6.

${ }^{50}$ Bakar, Tauhid dan Sains: Esai-Esai Tentang Sejarah dan Filsafat Sains Islam, 101; Osman Bakar, "Science and Technology for Mankind's Benefit: Islamic Theories and Practices - Past, Present, and Future," in Islamic Perspectives on Science and Technology (Singapore: Springer Singapore, 2016), 17-33, https://doi.org/10.1007/978-981-287-778-9_3. 


\section{F. Conclusion}

So, in this way, there will be two major themes in this case: First, that reality encompasses physical and metaphysical at ones; at the same time. Second, because only God, what is seen as a reality, then a view of what seems should be always associated with the entity behind it. The simple meaning can also be described as follows; if the view of the metaphysical reality has been sharp, the view of physical reality will be much sharper. Humans in treading reality with such models will be far more intact and comprehensive in seeing things; not being distracted by the visible appearance which is more deceptive than reflecting the true appearance.

Furthermore, elements of reality such as the concept of God, the concept of the universe (cosmology) and the 'reality of things', as well God attributes increasingly indicate God as an absolute reality. These elements are like objects of science and in other meanings can also be referred to as relative reality, whose status and observations also determine the size of the truth and validity of science. It can also be understood that reality when viewed from the perspective of Islam, it is centered on God. It belongs to God and will also return to God "innā lillāhi wa innā ilaihi räji'ün" or known as "theocentric". Here is the foundation of Islamic science in seeing reality is.]

\section{BIBLIOGRAPHY}

Abrahamov, Binyamin. Ilmu Kalam: Tradisionalisme dan Rasionalisme dalam Teologi Islam. Edited by Nuruddin Hidayat. Jakarta: Serambi Ilmu Sementara, 2002.

Akkach, Samer. Cosmology and Architecture in Premodern Islam: An Architectural Reading of Mystical Ideas. Edited by Seyyed Hossein Nasr. New York: State University of New York Press, 2005.

al-Ahwwani, Aḥmad Fuad. al-Falsafah al-Islämiyyah. Cairo: al-Maktabah al-Thaqafiy yah, 1962.

al-Anșāri, 'Abdullāh. Manāzil al-Sã̄irīn. Edited by A. Shirvani. Iran: Intisyarāt-i Furughi, 1380. 
al-Asfahani, al-Raghib. Mufradāt Alfāz al-Qur'ān. Edited by Sufyan 'Idnan Dawari. Beirut: al-Dar al-Shamiyah, 2009.

al-Ash'arī, Abu al-Hasan. Kitāb al-Luma'. Edited by Richard McCarty.

Beirut: Imprimerie Catholique, 1953.

Anīs, Ibrāhīm. al-Mu'jam al-Wāsiț. Cairo: Dār al-Ma'ārif, 1972.

Ansari, Abdul Haq. "The Doctrine of Divine Command: A Study in the Development of Ghazāli's View of Reality." Islamic Studies 21, no. 3 (1982): 1-47. https://doi.org/10.2307/20847207.

al-Baghdadi. Kitāb Ușūl al-Dīn. Istanbul: Matba'ah al-Dawlah, 1928.

al-Baqillani. Kitāb Tamhīd al-Awā'il wa Tadkhīl al-Dalāil. Edited by 'Imād al-Dīn Ahmad Haydar. Beirut: Mu’assasat al-Kutub al-Thaqāfiyyah, 1987.

al-Farabi, Abū Nașir Muhammad. Kitāb al-Siyāsah al-Madaniyyah. Edited by F. M. Najjar. Beirut: Dar El-Mashreq Publisher, 1964.

Bakar, Osman. "Science and Technology for Mankind's Benefit: Islamic Theories and Practices - Past, Present, and Future." In Islamic Perspectives on Science and Technology, 17-33. Singapore: Springer Singapore, 2016. https://doi.org/ 10.1007/978-981-287-778-9_3.

_- - Tauhid dan Sains: Esai-Esai tentang Sejarah dan Filsafat Sains Islam. Edited by Yuliam Liputo. Bandung: Pustaka Hidayah, 1994.

Blackburn, Simon. Oxford Dictionary of Philosophy. Oxford: Oxford University Press, 1996.

Ceylan, Yasin. Theology and Tafsir in the Major Works of Fakhr al-Din al-Razi. Kuala Lumpur: ISTAC, 1996.

Chittick, William C. The Self-Disclosure of God: Principles of Ibn al-Arabi's Cosmology. Edited by Seyyed Hossein Nasr. New York: State University of New York, 1998.

Fārūqī, Ismāîl Rājì al. Al Tawhid: Its Implications for Thought and Life. Virginia: International Institute of Islamic Thought, 2000. https://doi.org/ 10.2307/j.ctvk8w28n.

al-Ghazālī, Abū Ḥamīd Muḥammad ibn Muḥammad. al-Arbaînn fi Ușūl al-Dīn. Edited by Muștafā Abū al-'Alā. Cairo: Maktabah al-Jundi, n.d. 
—__. "Al-Hikmah fì Makhlūqātillāh." In al-Qusūr Awāli Min Rasāỉl al-Ghazālī, edited by Mușțafā Abū al-'Alā, 3rd ed. Cairo: Maktabah al-Jundi, 1972.

—__. Al-Iqtis̄ād fi al-I'tiqād. Edited by Insaf Ramaḍān. Beirut: Maktabah Kutaibah, 2003.

—_— al-Maqșād al-Asnā' min Asmā' Allāh al-Husnā. Edited by Mahmūid alNawāwi. Cairo: Maktabah al-Kulliyat al-Azhariyyah, n.d.

_—_. Ihyā̄' 'Ulūm al-Dīn. Edited by 'Abd al-'Azīz Sirwān. Beirut: Dār al-Qalam, n.d.

_—_. Mi'yār al-'Ilm. Cairo: Dār al-Ma'ārif, 1960.

___. Tahāâfut al-Falāsifah. Edited by Sulaymān Dunyā. Cairo: Dār al-Ma’ārif, 1966.

- — . Taḥāfut al-Falāsifah. Edited by Michael E Marmura. Utah: Brigham Young University Press, 2000.

al-Ḥakīm, Sưad. Al-Mújam al-Ṣüfi: al-Hikmah fi Hudūd al-Kalīmah. Beirut: Dandarah lil Ṭibā’ah wa al-Nașr, 1981.

Hye, Abdul. "Aliran Asy'ariyah." In Aliran-Aliran Filsafat Islam: Mu'tazilah, Asy'ariyyah, Maturidiyyah, Thahawiyah, Zhahiriyah, Ikhwan al-Safa, edited by M. M. Sharif. Bandung: Nuansa Cendekia, 2006.

Ibn Mandhūr, Muhạmmad bin Mukrim bin 'Ali Abū al-Faḍl Jamāl al-Dīn. Lisān alArab. Beirut: Dār al-Shadir, n.d.

Ibn Rushd, Abū al-Walid Muḥammad bin Ahmad. Al-Kashf'an Manāhij al-'Abdillāh fi 'Aqā’id Ahl al-Millah. Beirut: Markaz Dirasat al-Wahdah al-'Arabiyah, 1997.

Ismail, Mohd Zaidi. "Kosmos dalam Pandangan Hidup Islam dan Orientasi Sains Masyarakat Muslim." Islamia: Jurnal Pemikiran dan Peradaban Islam 3, no. 4 (2008): 5-25.

- _ . "The Cosmos as the Created Book and Its Implications for the Orientation of Science." In A Companion Worldview of Islam: Course Materials for Wise Summer School. Kuala Lumpur: CASIS-UTM, 2015.

al-Jurjani, 'Ali bin Muhammad bin 'Ali al-Zayn al-Sharīf. Kitāb al-Ta'rífät. Beirut: Dār al-Kutub al-'Ilmiyyah, 1983. 
al-Juwaini, Imām. Luma' al-'Adillah. Edited by Fawqiyah Ḥusayn Maḥmūd. Cairo, 1965.

Jaffer, Tariq. "Fakhr al-Dīn al-Rāzī on the Soul (al-Nafs) and Spirit (al-Rūḥ): An Investigation into the Eclectic Ideas of Mafātīh al-Ghayb." Journal of Qur'anic Studies 16, no. 1 (2014): 93-119. https://doi.org/10.3366/jqs. 2014.0133.

Massignon, L. Hallajj: Mystic and Martyr. Translated by H. Mason. Princetown: Princeton University Press, 1994.

Matsumoto, Akiro. "Unity of Ontology and Epistemology in Qaișari's Philosophy." In Consciousness and Reality, Studies in Memory of Toshihiko Izutsu, edited by Sayyid Jalāl al-Dīn Āshtiyānī, Hideichi Matsubara, Takashi Iwami, and Akiro Matsumoto. Tokyo: Iwanami Shoten Publisher, 1998.

Mustofa, Imron. "Fisika Atom sebagai Basis Filosofis Ilmu dalam Perspektif alGhazali." Epistemé: Jurnal Pengembangan Ilmu Keislaman 12, no. 1 (2017): 53-75. https://doi.org/10.21274/epis.2017.12.1.53-75.

Nasr, Seyyed Hossein. An Introduction to Islamic Cosmological Doctrines: Conceptions of Nature and Methods Used for Its Study by the Ikhwān al-Safā, al-Bīrūnī, and Ibn Sinnā. London: Thames and Hudson, 1978.

Nasution, Harun. Falsafat dan Mistisisme dalam Islam. Jakarta: Bulan Bintang, 1978.

Poejawijatna. Manusia dan Alamnya. Jakarta: Bina Aksara, 1983.

al-Qashani, Kamāl al-Dīn 'Abd al-Razāq. Ișțilāhāat al-Sūfiyyah. Edited by Kamāl Ibrāhīm Ja'far. Cairo: al-Hay'ah al-Mișriyyah al-'Ammah li al-Kitāb, 1981.

al-Rāzi, Fakhr al-Dīn. Mafătịh al-Ghayb. Beirut: Dār 'Ihya' al-Turath al-A'rab, 1420.

Rivauzi, Ahmad. "Landasan Filosofis Pemikiran Tasawuf Abdurrauf Singkel tentang Allah, Manusia, dan Alam." Jurnal Theologia 28, no. 2 (2017): 299328.https://doi.org/10.21580/teo.2017.28.2.1451.

Rowson, Everett K. A Muslim Philosopher on the Soul and Its Fate. New Haven: American Oriental Society, 1998.

al-Ṭahāwi, Abū Ja'far. Al-Aqīdah al-Ṭahāwiyyah. Edited by Majdi Abū 'Arisy. Beirut: Dār al-Bayariq, 2001. 
Saleh, Sujiat Zubaidi. "Kritik Ibn Rusyd terhadap Pandangan Para Filsuf tentang Ketuhanan." Tsaqafah 5, no. 1 (2009): 97. https://doi.org/10.21111/ tsaqafah.v5i1.149.

Salīb, Jamīl. Tarìkh al-Falsafah al-'Arābiyyah. Beirut: Dār al-Kitāb al-Ranani, 1970.

Schimmel, Annemarie. Mystical Dimensions of Islam. Carolina: The University of North Carolina Press, 1975.

Smith, Donald. The Cosmos. Canada: Benyamin WA, 1976.

Zarkasyi, Hamid Fahmy. Al-Ghazali's Concept of Causality: With Reference to His Interpretations of Reality and Knowledge. Kuala Lumpur: IIUM Press, 2010.

- - . "Epistemological Implication of al-Ghazzāli’s Account of Causality." Intellectual Discourse 26, no. 1 (2018): 51-73. https://journals.iium.edu.my/ intdiscourse/index.php/islam/article/view/1131. 
